\title{
PHYSIOLOGICAL AND ENZYMATIC ALTERATIONS IN PAPAYA SEED DURING STORAGE ${ }^{1}$
}

\author{
DENISE CUNHA FERNANDES DOS SANTOS DIAS ${ }^{1}$; WAGNER TOMPSON ESTANISLAU2; \\ FERNANDO LUIZ FINGER ${ }^{1}$; EVELINE MANTOVANI ALVARENGA ${ }^{1}$; LUIZ ANTÔNIO DOS SANTOS DIAS ${ }^{1}$
}

\begin{abstract}
This study was done to evaluate the physiological and enzymatic alterations in papaya (Carica papaya L.) seeds during storage period. Seeds were extracted from mature fruits of Formosa group papaya hybrid Tainung 01 . The sarcotesta was removed by rubbing the seeds on a wire screen under running water and then dried to the moisture content (MC) of 5, 8 or $11 \%$ The seeds were packed in multilayer paper bags, polyethylene bags, aluminum foil pouch and metallic canisters and stored for 15 months under laboratory conditions. Seeds were evaluated, at three month interval, for MC, germination, and the activity of acid phosphotase (AP) and malate dehyrogenase (MDH) was evaluated with the use of amide gel $(12 \%)$ electrophoresis. The fresh seeds had post-harvest dormancy, which was broken after six month storage. Independent of the package type, the seeds could be stored for 12 months with 8 or $11 \% \mathrm{MC}$ under ambient conditions. There was no association between seed deterioration and alterations in AP and MDH activity.
\end{abstract}

Index terms: preservation, package, physiological quality, Carica papaya L.

\section{ALTERAÇÕES FISIOLÓGICAS E ENZIMÁTICAS EM SEMENTES DE MAMÃO DURANTE O ARMAZENAMENTO}

\begin{abstract}
RESUMO - O trabalho foi realizado com objetivo de avaliar as alterações fisiológicas e enzimáticas em sementes de mamão (Carica papaya L.) durante o armazenamento. Sementes do grupo Formosa, híbrido Tainung 01, extraídas de frutos maduros, tiveram a sarcotesta removida por meio de fricção em peneira sob água corrente. Foram então submetidas à secagem até atingir graus de umidade de 11, $8 \mathrm{e}$ 5\%. Em seguida, foram acondicionadas em papel multifoliado, saco de polietileno, papel aluminizado tipo 'pouch' e lata e armazenadas em ambiente de laboratório por 15 meses. Antes do armazenamento e a cada três meses, as sementes foram avaliadas quanto ao grau de umidade e germinação. Determinouse ainda a atividade das enzimas fosfatase ácida e malato desidrogenase utilizando-se eletroforese em gel de amido a 12\%. Verificou-se que sementes recém-colhidas apresentam dormência pós-colheita que é superada após seis meses de armazenamento. Sementes de mamão podem ser armazenadas com 8,0 ou $11 \%$ de água, por 12 meses, em condição ambiente, independente do tipo de embalagem. Não há associação entre deterioração das sementes de mamão durante o armazenamento e alterações nos sistemas enzimáticos fosfatase ácida e malato desidrogenase.
\end{abstract}

Termos para indexação: conservação, embalagem, qualidade fisiológica, Carica papaya L.

${ }^{1}$ Submitted on 19/08/2009. Accepted for publication on 04/11/2009.

${ }^{1}$ Prof. Associado, Depto. de Fitotecnia, Universidade Federal de Viçosa, 36570-000 - Viçosa - MG, e-mail: dcdias@ufv.br
${ }^{2}$ Eng. Agr., D.S.,Depto. de Fitotecnia, Universidade Federal de Viçosa, 36570-000 - Viçosa - MG. 


\section{INTRODUCTION}

Commercial plantation of papaya depends upon propagation through seeds, since the asexual propagation, through, grafting or in vitro multiplication does not provide satisfactory results (Oliveira and Trindade, 2000). On the other hand, the physiological quality of seeds still is an obstacle to produce papaya seedlings, because of slow and irregular germination. These problems have been attributed to the post-harvest dormancy induced by the sarcotesta (Yahiro and Oryoji, 1980; Viggiano et al., 2000a; Martins et al, 2005; Tokuhisa et al., 2007a, 2007b). Maintenance of physiological quality of papaya seed during storage also is difficult (Ellis et al., 1991; Viggiano et al., 2000b).

The available informations regarding the physiological behavior of papaya seeds in storage are contradictory. Ellis et al. (1991) classified these seeds as intermediary because of sensibility to desiccation when dried to below $5 \%$ moisture content $(\mathrm{MC})$ and low temperature injury $\left(-20{ }^{\circ} \mathrm{C}\right)$, and found that seeds stored at $15{ }^{\circ} \mathrm{C}$ with 8.0 to $9.4 \% \mathrm{MC}$, maintained for 12 months the original level of germination $(89 \%)$. However, these results were not confirmed in other studies. Magill et al. (1994) reported that some seeds lots survived desiccation to $5 \% \mathrm{MC}$. Similarly, Althoff and Carmona (1999) found that seeds did not tolerate low temperatures $\left(5^{\circ} \mathrm{C}\right.$ and $\left.-18{ }^{\circ} \mathrm{C}\right)$, which was not confirmed by Santos et al. (1999), who obtained better conservation of seeds at $7 \% \mathrm{MC}$ at $5{ }^{\circ} \mathrm{C}$, independent of the package type used. Earlier studies had shown that papaya seeds stored at 15 or $5{ }^{\circ} \mathrm{C}$ with 9.5 or $10.1 \% \mathrm{MC}$, maintained viability for nine months. Arumugam and Shanmugavelu, (1977) and Singh and Singh (1981), reported that the viability of papaya seeds could be maintained for eight months when packed in polyethylene bags or plastic canisters stored at 4 to $6{ }^{\circ} \mathrm{C}$ and $40 \%$ relative humidity $(\mathrm{RH})$.

Studies of Salomão and Mundim (2000) showed that the drying to 5.3 or $6.9 \% \mathrm{MC}$, followed by exposure to $-20{ }^{\circ} \mathrm{C}$ and $\mathrm{GA}_{3}$ treatment allowed for good conservation of papaya germplasm, suggesting thus, that these seeds behave as orthodox seed in storage. To determine the most adequate conditions for storing seeds of papaya 'Sunrise Solo', Viggiano et al. (2000b) did not reach conclusive results by storing seeds for eight months with $7.2 ; 9.3$ or $11.3 \% \mathrm{MC}$, in aluminum foil pouches, or multilayered paper bags, in ambient conditions or cold room, but found that aluminum foil pouch was inadequate for quality maintenance of seeds stored at $10{ }^{\circ} \mathrm{C}$ and $63 \%$ RH. Martins et al. (2005) reported that germination and vigor of seed packed in permeable packages declined after six months when stored under room conditions, while Araújo et al. (2005) showed that physiological quality of seeds of Solo group, cv. Golden did not change when stored for one year in polyethylene bags in a refrigerator.

These studies show that there are no assured criteria regarding $\mathrm{MC}$, package type, and the environmental conditions for successful storage of papaya seeds. There is also no information regarding biochemical changes caused by seed quality loss, especially those related to the activity of enzymes related to the deterioration process. The enzymes play an important role in the progress of seed deterioration and changes in their activity can be an indication of quality loss (Copeland and McDonald, 1995). The relationship between seed deterioration and the enzymes involved in lipid peroxidation, free radical removal, and seed respiratory metabolism also has been studied (Betty and Finch-Savage, 1996; Shen and Odén, 1999).

Malate dehyrogenase (MDH) has an important function in the Kreb cycle where it catalyzes conversion of malate oxalacetate, and participates in the movement of malate through the mitochondrial membrane, and in carbon-dioxide fixation in plants (Taiz and Zeiger, 1994). Shatters et al., (1994) reported that activity of MDH was less affected by different aging treatments of soybean seeds, and Kalpana and Mandhava Rao (1997) found a decline in its activity with aging of guandu seeds. Vieira (1996) found an increased number of MDH bands in aged cotton seeds, and concluded that the enzyme, involved in respiration can have high activity in the deteriorated seeds.

The acid phosphotase (AP) are a group of enzymes that catalyze hydrolysis of phosphate monoesters, participating in the dephosphorylation of proteins (Duff et al., 1994). Spinola et al., (2000) reported that AP by acting on membranes phospholipids induces their peroxidation, and the alterations in isozymes of AP and peroxidases could be effectively used for vigor tests to evaluate quality of corn seeds subjected to accelerated ageing; while the pattern of MDH remained unaltered with advancing deterioration.

Considering that the papaya seeds have high commercial value, about US\$ 4000.00 per $\mathrm{kg}$, the losses in storage under inadequate conditions become unacceptable, thus warranting studies regarding good storage of its seeds. This study was done to evaluate the physiological 
and enzymatic alterations of papaya seeds with different MC stored in different types of packages.

\section{MATERIAL AND METHODS}

The study was done the "Laboratório de Pesquisa em Sementes do Departamento de Fitotecnia da UFV". Hermaphrodite fruits of papaya Formosa group, hybrid Tainung 01, were produced by the "Hidra e Hera Sementes" company, located in the municipality of Linhares, ES. The seeds were extracted from the fruits at maturation stage- 5 (more than $75 \%$ yellow external surface of fruit peel) (Aroucha et al., 2004). The sarcotesta was removed by rubbing the seeds on a wire screen under running water. The seeds were initially dried to the MC of about $11 \%$ by placing them on an absorbent paper towel over a laboratory bench and then adjusted to $11.0,8.0$ and $5.0 \%$, by drying in a force air fixed bed dryer at $40{ }^{\circ} \mathrm{C}$. To monitor the MC during drying the samples with known initial mass and $\mathrm{MC}$ were periodically removed for weighing. The final mass of the samples corresponding to each desirable MC was previously determined through the equation of Cromarty et al. (1985).

The seeds were packed in four types of packages: 1) multilayered kraft paper bags with $100 \mathrm{~g} \mathrm{~m}^{-2}$ density, $100 \mathrm{~g}$ capacity, $24 \mathrm{~cm}$ height and $10 \mathrm{~cm}$ width;2) polyethylene bags- $150 \mu$ thickness, $50 \mathrm{~g}$ capacity, $24 \mathrm{~cm}$ height and $12 \mathrm{~cm}$ width; 3) aluminum foil pouch, $163 \mathrm{~g} \mathrm{~m}^{-2}$ density, $50 \mathrm{~g}$ capacity, $18 \mathrm{~cm}$ height and $13 \mathrm{~cm}$ width; 4) metallic canister - made from tin coated flander sheet, $50 \mathrm{~g}$ capacity, $7.4 \mathrm{~cm}$ diameter. The polyethylene bags and aluminum foil pouch and the canisters were machine sealed. The seeds in respective package were stored for 15 months, from March 2004 to June 2005, under laboratory conditions (25 $\pm 3{ }^{\circ} \mathrm{C}$ and $\left.70 \pm 5 \% \mathrm{RH}\right)$. The samples were removed at three month interval to determine $\mathrm{MC}$, germination, and the activity of MDH and AP.

The MC was determined using the oven method by drying for $24 \mathrm{~h}$ at $105 \pm 3^{\circ} \mathrm{C}$, with use of two sub samples of 100 seeds each, according to the "Regras para Análise de Sementes" (Brasil, 1992). The results were expressed as percent MC wet base (wb). Seed germination was tested by the paper roll method in four replications of 50 seeds each. The seeds were placed on a blotter paper previously moistened with water 2.5 times the dry paper weight and the paper with seeds was rolled. The seeds in roles were incubated in a germinator at alternating temperature of 20/35 ${ }^{\circ} \mathrm{C}(16 \mathrm{~h} / 8 \mathrm{~h}$, respectively). The first counts of germination were taken after 15 days and the final germination was determined after 30 days. The results were expressed as mean percent normal seedlings (Brasil, 1992).

Analysis of AP and MDH was done by electrophoresis. Five hundred milligram seeds were macerated in liquid nitrogen with use of a porcelain mortar and pastel. The modified extracting solution (Alfenas et al., 1991) was added to the macerate in the proportion of $1: 4(\mathrm{w} / \mathrm{v})$ followed by addition of $30 \mathrm{mg}$ de polivinil pirrolidone and $1 \%$ of b-mercaptoetanol to remove the phenolic compounds (Alfenas et al., 1991). The mixture was centrifuged for 30 minutes at $14.000 \mathrm{rpm}$, at $4{ }^{\circ} \mathrm{C}$, and the extract was filtered through Whatman $3 \mathrm{M}(1.5 \times 0.8 \mathrm{~cm})$ chromatographic paper. The $12 \%$ starch gel was prepared with use of $60 \mathrm{~g}$ corn starch in $500 \mathrm{ml}$ of the buffer solution suited for each enzyme system. The runs were carried out for 5 hours at $180 \mathrm{~V}$, at $4{ }^{\circ} \mathrm{C}$, in a turf containing $100 \mathrm{~mL}$ of the appropriate electrophoresis buffer (Conkle et al., 1982). The development of $\mathrm{MDH}$ was carried out according to Acquaah (1992), in dark at $30^{\circ} \mathrm{C}$ and that of AP according to Soltis et al. (1983), at $25^{\circ} \mathrm{C}$, till the appearance of bands. The developed gels were fixed for 12 hours, at $4{ }^{\circ} \mathrm{C}$ in $10 \%$ glycerin (Alfenas et al., 1991).

Statistical analysis: The experiment was done in completely randomized design, with four replications and analyzed in split plot design. The three MC (5, 8 and 11\%) and the four package types (multilayer paper, polyethylene, aluminum foil pouch and metal canister) were allocated to the factorial scheme $(3 \times 4)$ and the six storage periods $(0$, $3,6,9,12$ and 15 months) to the split plots. Regression analysis was used for storage period. The MC data were not subjected to statistical analysis. All analysis were processed with use the program SAS (SAS, 1989), procedure GLM.

\section{RESULTS AND DISCUSSION}

After three month storage, the seeds packed in multilayer paper or polyethylene bags absorbed moisture and reached the hygroscopic equilibrium with the atmosphere (Table 1). Padilha et al. (1998), found polyethylene package suitable for soybean seeds because it avoided gas exchange with the atmosphere, which was not confirmed in this work. In the impermeable packages (aluminum foil pouch and metallic canisters), the seed moisture practically remained similar to the original levels, indicating little or no moisture exchange between the seeds and the external atmosphere. Only seeds at $5 \% \mathrm{MC}$ in aluminum foil pouch had a small increase of MC to $6 \%$ after 12 and 15 month storage. Similar results were reported by Viggiano et al. (2000b). 
TABLE 1. Changes in mean moisture content (wet base) of papaya seeds with different initial moisture content packed in different types of packages.

\begin{tabular}{lrrrrrr}
\hline \multirow{2}{*}{ Package type } & \multicolumn{5}{c}{ Storage period (months) } \\
& Initial moisture content $(\%)$ & \multicolumn{1}{c}{3} & \multicolumn{1}{c}{6} & \multicolumn{1}{c}{9} & \multicolumn{1}{c}{12} & \multicolumn{1}{c}{15} \\
\cline { 3 - 7 } Multilayer paper bag & 5.0 & 9.0 & 9.4 & 9.6 & 9.6 & 10.4 \\
& 7.9 & 9.4 & 10.6 & 10.1 & 9.7 & 10.2 \\
& 11.1 & 10.2 & 10.9 & 10.5 & 9.2 & 10.5 \\
\hline \multirow{3}{*}{ Polyethylene bag } & 5.0 & 8.8 & 9.5 & 8.7 & 10.2 & 11.0 \\
& 7.9 & 9.6 & 10.4 & 8.7 & 10.2 & 11.4 \\
& 11.1 & 11.7 & 10.6 & 9.5 & 11.0 & 11.3 \\
Aluminum foil pouch & 5.0 & 4.9 & 5.5 & 5.6 & 6.0 & 6.1 \\
& 7.9 & 8.0 & 8.3 & 8.5 & 8.4 & 8.3 \\
& 11.1 & 11.1 & 11.4 & 10.9 & 11.2 & 11.6 \\
Metallic canister & 5.0 & 5.4 & 5.5 & 5.3 & 6.2 & 6.4 \\
& 7.9 & 8.1 & 8.3 & 8.0 & 8.3 & 8.1 \\
& 11.1 & 11.6 & 11.1 & 11.3 & 11.5 & 11.4 \\
\hline
\end{tabular}

During the 15-months storage period the germination percent of seeds packed in multilayer paper bags at any $\mathrm{MC}$, kept on increasing for nine months and then started to decrease (Figure 1A). Martins et al. (2005) reported decline in germination percent and vigor of seeds stored under ambient conditions in permeable packages. The increase of germination percent with storage time (Figure 1A) can be attributed to breakdown of the post-harvest dormancy. There are controversial reports regarding the occurrence of post-harvest dormancy in papaya seeds. Singh and Singh (1981) and Santos et al. (1999) found maximum germination percent in recently harvested seeds that decreased rapidly during storage. On the other hand, Yahiro and Oryoji (1980) and Viggiano et al. (2000a,b) found low germination percent due to post-harvest dormancy, which was also confirmed by Aroucha et al. (2004) in seeds of the cv. Golden and of the hybrid Tainung 01 , independent of the fruit maturity stage, however, needed a storage period of 8 to 16 months, respectively, for germination to reach about $80 \%$, which also suggests that the more intense dormancy of the seeds of hybrid Tainung 01. On the other hand, Viggiano et al. (2000b) observed that dormancy of seeds with initial germnation of $9 \%$, packed in multilayer paper bags, was broken in two months when the germination reached $62 \%$, but after four months storage it declined significantly.

The multilayer paper bags are knowingly permeable that allow for exchange of water vapors between seeds and the external atmosphere (Table 1). The initial 5\% MC of seeds reached $9 \%$ in the third month of storage and this level was maintained till the end of 15 months. The seeds with initial MC of $8 \%$ behaved similarly. Althoff and Carmona, (1999) however, reported that this type of package was appropriate for preserving papaya seeds for two years in the environmental conditions of Brasília-DF.

The germination percent of seeds with 8 or $11 \% \mathrm{MC}$ packed in polyethylene bags (Figure 1B) also increased till 10th and 9th month of storage, reaching 91.5 and $82.5 \%$, respectively and then started to decrease, reaching 80 and $71 \%$, respectively after 15 months. It should be noted that decline of germination percent of seeds with $5 \% \mathrm{MC}$ started earlier, from the seventh month, and at the end of the 15 -months storage reached $46 \%$, which was much lower than that of seeds with 8 or $11 \% \mathrm{MC}$.

As in multilayer paper bags, the MC content of seeds packed in polyethylene bags increased with increasing storage period, especially of seeds with initial MC of 5\% ( table 1) that could have contributed to the decline of percent seed germination along the storage period due to increase in the respiratory activity. 

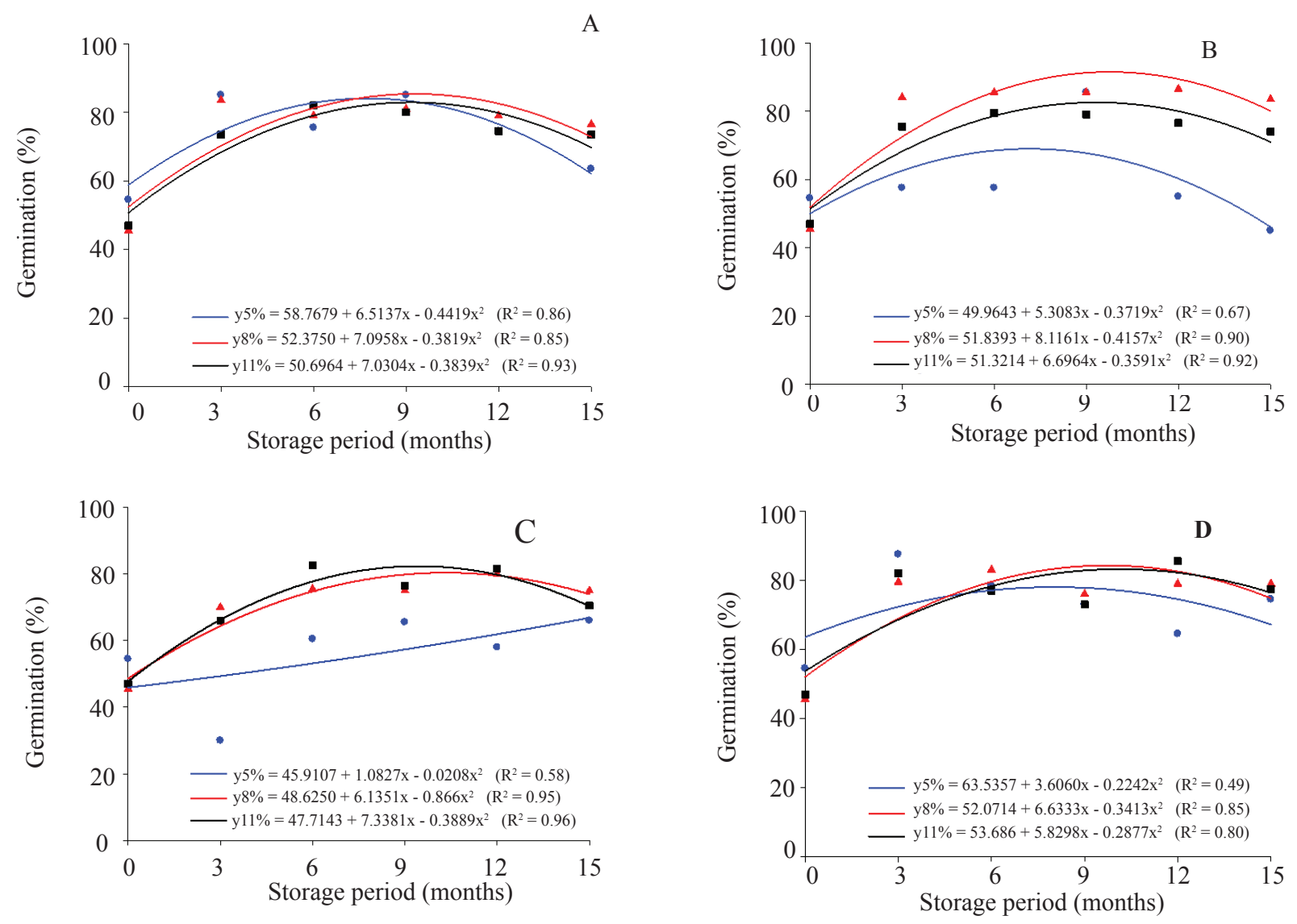

FIGURE 1. Germination estimate (\%) of papaya seed, without sarcotesta, with moisture content of $5 \%\left(\_\right), 8 \%\left(\_\right)$ and $11 \%\left(\_\right)$packed in multilayered paper bag (A), polyethylene bag (B), aluminum foil pouch (C) or metallic canister (D) and stored for $\mathbf{1 5}$ months under laboratory ambient conditions.

The germination percent of seeds with $5 \% \mathrm{MC}$ and packed in aluminum foil pouch, increased continually for 12 months of storage, although the values were lower than those of seeds at 8 or $11 \% \mathrm{MC}$ (Figure 1C); but at the end of 15 months it was similar to seed at any MC. The germination of seeds with 8 or $11 \%$ MC increased continually till 11 and 9 months, respectively, with maximum of 81.5 and $82.3 \%$ respectively, then decreased, similar to that in seeds stored in multilayer paper bags (Figure 3) and metallic canisters (Figure 1D). The germination percent of seeds at $5 \%$ MC packed in metallic canisters was higher than that of seeds at 8 or $11 \% \mathrm{MC}$ till sixth month. However, after this period the percent germination of seeds with $5 \% \mathrm{MC}$, started to decrease, but not of seeds with other MCs, whose germination continued to increase till about 10 months, and then started to decline. Viggiano et al. (2000b) reported that the germination of papaya seeds with $11.3 \% \mathrm{MC}$ packed in aluminum pouches declined significantly after four months of storage under ambient conditions, while the seeds with 7.2 and $9.3 \% \mathrm{MC}$ preserved better.

The seed MC for packing in impermeable packages should be in range of 5\% and 9\% (Carvalho and Nakagawa, 2000), which maintains low respiratory activity and consequently reduces deterioration rate. In general, this study showed that the seeds with 8 or $11 \%$ MC, packed in polyethylene bag, aluminum foil pouch or metallic canister maintained higher germination percent during storage compared to the seeds with 5\% MC (Figure 1D). It is noteworthy that in the impermeable packages the seed MC reached only $6 \%$ and maintained till the end of 15 -months storage period, while in polyethylene and multilayered paper bags it reached 12.1 and $11.5 \%$ respectively (Table 1). However, although the seeds at $5 \% \mathrm{MC}$ attained similar $\mathrm{MC}$ at the end of the storage period, the germination percent 
of seeds in polyethylene bags was lower than those packed in multilayer paper bags. Thus, this behavior cannot be attributed solely to seed MC. The germination of seed with 8 or $11 \%$ MC was similar in different packages (Figure 1 ), which did not happen with seeds having $5 \% \mathrm{MC}$. This phenomenon can not be attributed to the drying process leading to low water content, because the seeds with $5 \%$ $\mathrm{MC}$ in multilayered paper bags and in metallic canisters germinated similar to other seeds. Althoff and Carmona (1999) reported that papaya seeds tolerate desiccation to $5 \% \mathrm{MC}$ without losing the germination capacity, but do not tolerate low temperature during storage. On the other hand,
Santos et al. (1999) reported good germination of seeds with $7 \% \mathrm{MC}$ stored in a refrigerator $\left(2\right.$ to $\left.5{ }^{\circ} \mathrm{C}\right)$, independent of the package used.

Germination at first count, that indicates germination velocity (Figure 2), a component of seed vigor (Figure $2 \mathrm{~A}$ ), of seeds with $5 \% \mathrm{MC}$ packed in multilayer paper bags increased continually for about nine months while of those with 8 or $11 \%$ for about ten months due to dormancy breakdown, and then started to decrease. The germination pattern was similar for seeds stored in canisters (Figure 2D) and the results were coherent with the total germination. (Figure 1A \& 1D).
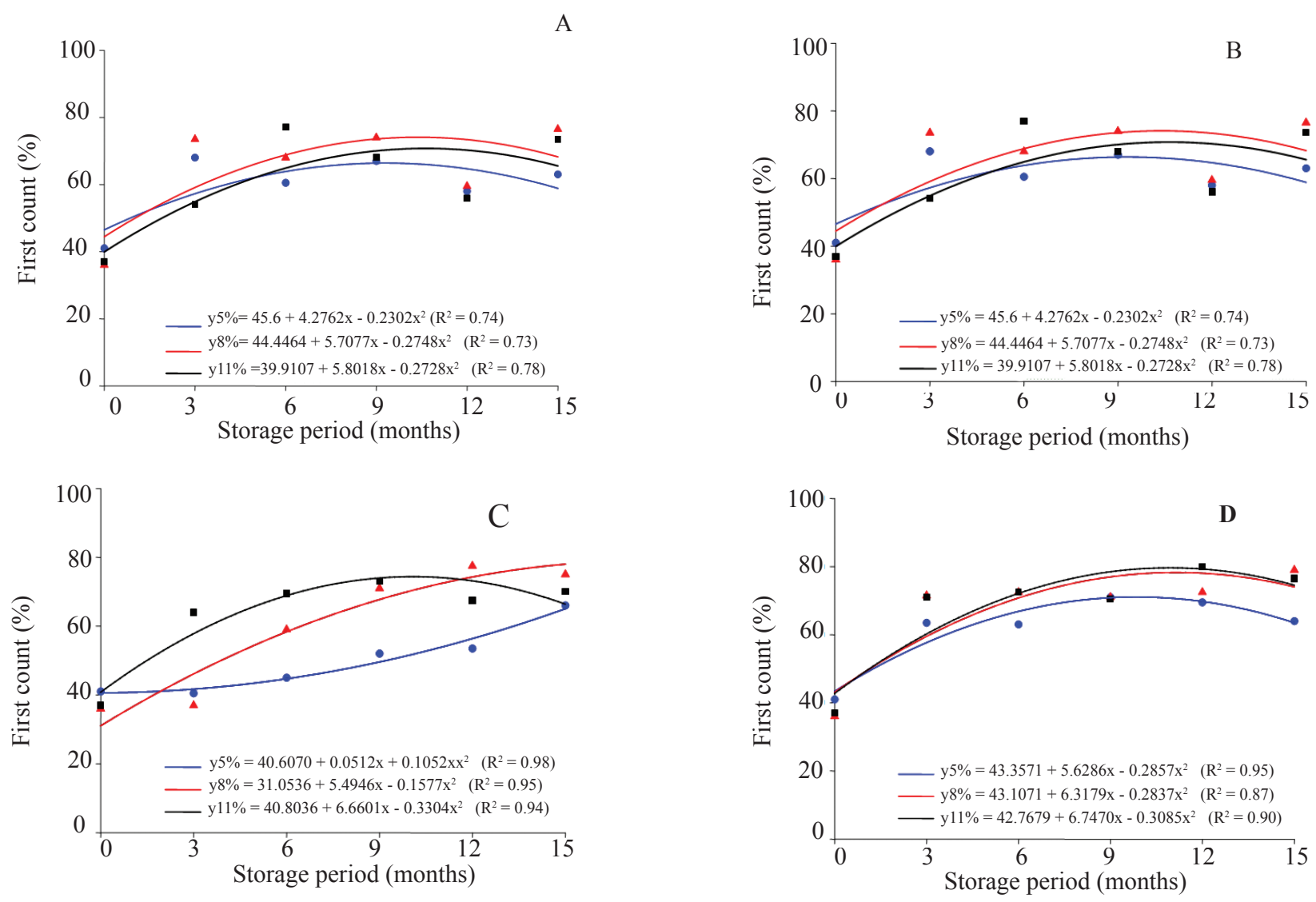

FIGURE 2. Estimated first count of germination (\%) of papaya seeds, without sarcotesta, with moisture content of $5 \%(\ldots), 8 \%$ (_) or $11 \%(\ldots)$ packed in multilayered paper bag $(\mathrm{A})$, polyethylene bag $(\mathrm{B})$, aluminum foil pouch (C) or metallic canister (D) and stored for 15 months under laboratory ambient conditions.

During the entire storage period, the most and least favorable performance of seeds with 11 or $5 \% \mathrm{MC}$ was of those packed in polyethylene bags (Figure 2B), respectively. The germination velocity of seeds with 8 or $11 \% \mathrm{MC}$ was similar, and increasing till ninth month, and then started to decline continuously. Viggiano et al. (2000b) reported a significant increase of germination velocity, due to dormancy breakdown from the second month of storage.

In aluminum foil pouches (Figure 2C), seeds with $11 \% \mathrm{MC}$ preserved best with increasing germination till the 10-months storage, and then started to decrease. The 
germination velocity of seeds with $8 \%$ MC increased linearly till the end of the storage period, due to gradual breakdown of dormancy. The germination velocity of seeds with 5\% MC also increased, especially after third month, although slowly during the first 12 months, than the seeds with 8 or $11 \%$ MC. Similar pattern was found for total germination (Figure 2C). The germination velocity of seeds with 8 or $11 \%$ MC packed in canisters increased for 12 months and that of seeds with 5\% MC for nine months and then started to decrease (Figure 2D). In general, the performance of these seeds packed in impermeable packages was lower than that of seeds with 8 or $11 \% \mathrm{MC}$.

Zimogram of AP system (Figure 3), shows that, in general, its activity in seeds varied, depending upon the package, initial MC and storage duration, thus no pattern could be established for the storage period. In general, there were less intense bands for the seeds with $5 \% \mathrm{MC}$, compared to those of seeds with 8 or $11 \% \mathrm{MC}$, packed in aluminum foil pouch, or multilayered paper bag till six months storage. Only in the seeds packed in polyethylene or multilayered paper bags showed higher activity, which was similar to that of seeds with 8 or $11 \%$ MC. Thus, the lower activity of this enzyme occurred in seeds with $5 \%$ MC packed in impermeable aluminum foil pouch or in canister. The germination of such seeds packed in polyethylene bag or aluminum foil pouch, (Figure 1), was lower than the seeds with 8 or $11 \%$ MC. Thus, no relationship between AP activity and behavior of papaya seeds in storage could be established, except that the enzymatic activity, in general, was lower in seeds with lower MC.

The AP catalyzes hydrolysis of monoesters by acting on membrane phospholipids (Ayoana et al., 2001). Some researchers reported decline of AP activity with increasing seed age (Chauhnan et al., 1985; Sung e Jeng, 1994). Decrease in the activity of this enzyme system during storage of cotton seeds was reported by Freitas et al. (2006), suggesting a positive correlation between low activity of the enzymes and decline of seed vigor. A similar relationship was reported for artificially aged maize seeds (Spinola et al., 2000). On the other hand, Rajagopal and Sen-Mandi (1992) found high activity of this enzyme in the embryo of artificially aged rice seed, which was also confirmed by Brandão Jr. (1999) in the corn seeds after $96 \mathrm{~h}$ of artificial ageing.

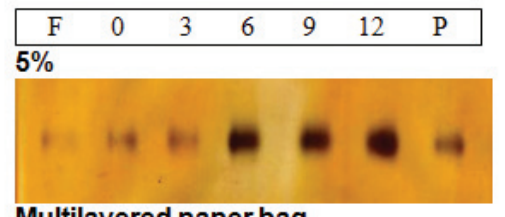

Multilayered paper bag

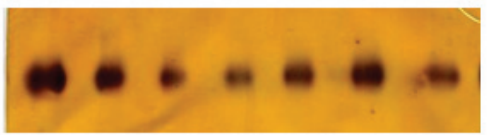

Polyethylene bag

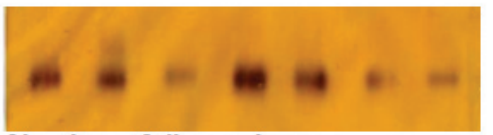

Aluminum foil pouch

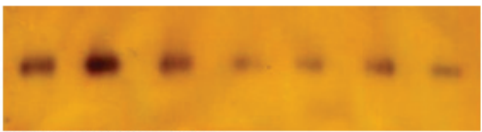

Metallic canister

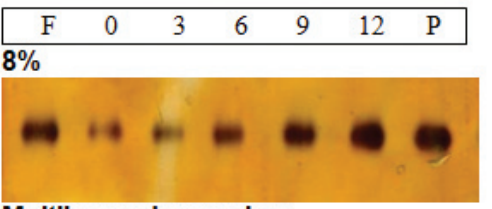

Multilayered paper bag

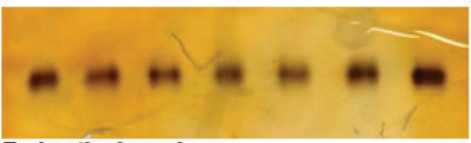

Polyethylene bag

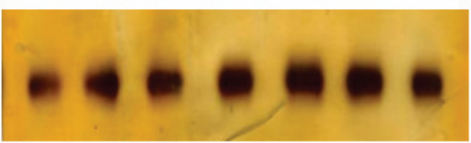

Aluminum foil pouch

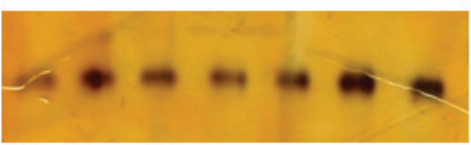

Metallic canister

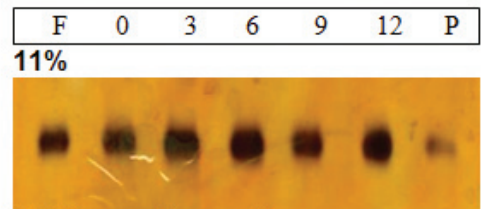

Multilayered paper bag

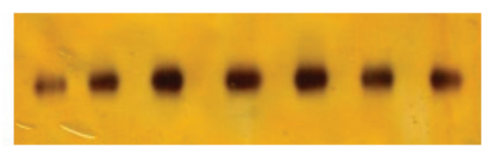

Polyethylene bag

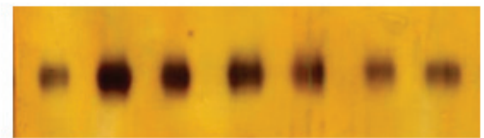

Aluminized paper pouch

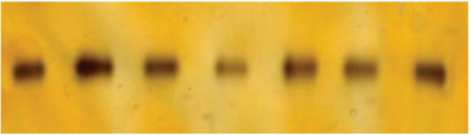

Metallic canister

FIGURE 3. Electrophoretic pattern of acid phosphatase in papaya seeds, without sarcotesta, with 5,8 or $11 \%$ moisture content packed in different types of packages and stored for 12 months $(0,3,6,9$ and 12 months). $F$ (fresh seeds) and $P$ (standard). 
It must be emphasized that there was no difference in the intensity of AP bands (Figure 3) along the storage period, especially for seeds with $8 \% \mathrm{MC}$ packed in aluminum foil pouch or multilayered paper bags, and in seeds with $11 \% \mathrm{MC}$ in multilayered paper bag, thus showing a lack of relationship between its activity and the behavior of stored papaya seeds.

The electrophoretic profile of MDH (Figure 4) revealed high activity in the freshly harvested seeds. In seeds with 5\% MC packed in multilayer paper bags, its activity started to declined from the ninth month of storage, and was similar to that in seeds with 5 or $8 \%$ MC packed in polyethylene bags, without expressive alterations during the entire storage period. In this package, there was reduction of MDH activity after 6 and 9 month storage, only in seeds with $11 \% \mathrm{MC}$. On the other hand, in the impermeable packages (aluminum foil pouch and metallic canisters) there was high activity of this enzymatic system during the entire storage period, independent of seed $\mathrm{MC}$, thus no relationship with physiological quality of seeds during storage could be established (Figures 1 and 2). Spinola et al. (2000) also did not find relationship between MDM activity and the seed vigor of corn, since the electrophoretic pattern remained unaltered with the increasing deterioration. In soybean seeds, Shatters et al. (1994) found that the MDH activity is not much affected by the artificial aging. Santos et al. (2004), on the contrary, concluded that in common beans, the activity of AP, MDH, glutamate dehydrogenase and esterase was affected by the aging time period and the initial quality of the seed lot.

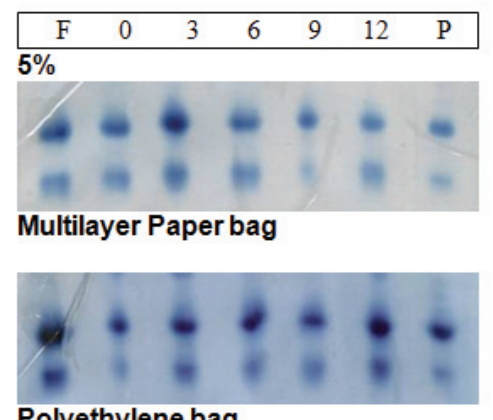

Polyethylene bag

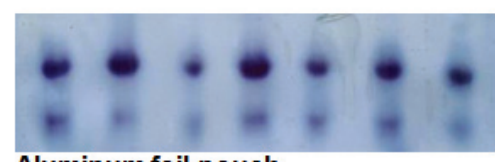

Aluminum foil pouch

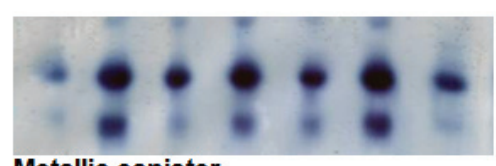

Metallic canister

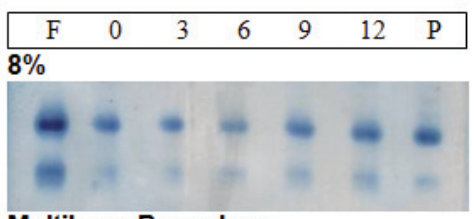

Multilayer Paper bag

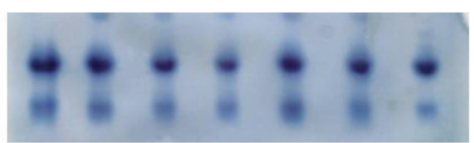

Polyethylene bag

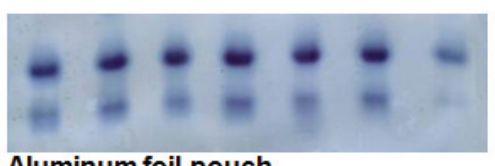

Aluminum foil pouch

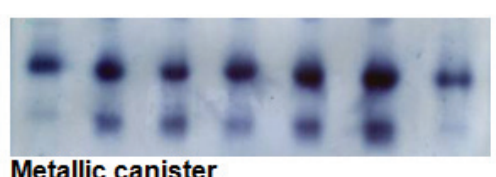

Metallic canister

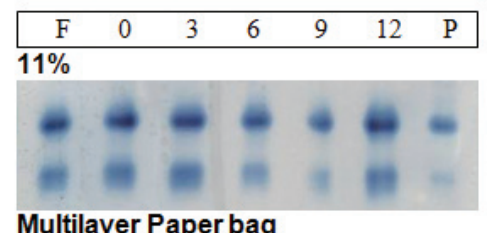

Multilayer Paper bag

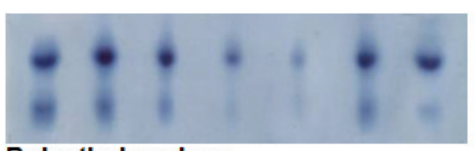

Polyethylene bag

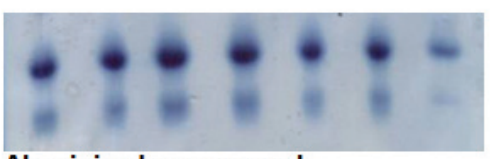

Aluminized paper pouch

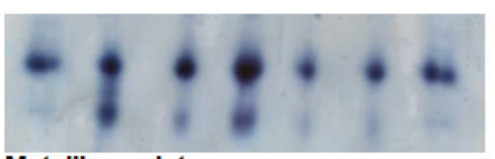

Metallic canister

FIGURE 4. Electrophoretic pattern of malate dehydrogenase in papaya seeds, without sarcotesta, with 5,8 or $11 \%$ moisture content packed in different types of packages and stored for 12 months $(0,3,6,9$ and 12 months). F (fresh seeds) and P (standard).

\section{CONCLUSIONS}

Freshly harvested papaya seeds show dormancy that was broken after six month storage under ambient conditions.

Papaya seeds with moisture content of 8 or $11 \%$ can be stored in ambient conditions for 12 months in permeable or impermeable packages.

There is no association between the deterioration of papaya seeds during storage and alterations of the enzymatic systems of acid phosphatase and malate dehydrogenase.

\section{REFERÊNCIAS}

ACQUAAH, G. Practical protein electrophoresis for genetic research. Oregon: Dioscorides Press, 1992.131p.

ALFENAS, A. C. PETERS, I.; BRUCE, W.; PASSADOS, G. C. Eletroforese de proteínas e isoenzimas de fungos e essências florestais. Viçosa: UFV, 1991. 242p.

ALTHOFF, M.A.; CARMONA, R. Conservação de sementes de mamão (Carica papaya L. - Caricaceae). 
Revista Brasileira de Sementes, v.21, n.1, p.151-156, 1999.

AOYAMA, H.; CAVAGIS, A.D.M.; TAGA, E.M.; FERREIRA, C.V. Endogenous lectin as a possible regulator of the hydrolysis of physiological substrates by soybean seed acid phosphatase. Phytochemistry, v.58, n.1, p.221225, 2001.

ARAÚJO, E.C.; BALBINOT, E.; MENDONÇA, A.V.R.; SILVA, R.F. Efeito do armazenamento na qualidade fisiológica de sementes de mamão (Carica papaya L.) em função da posição no fruto. In: Papaya Brasil - mercado e inovações tecnológicas para o mamão. Vitória: INCAPER. 2005. p.270-272.

AROUCHA, E.M.M.; SILVA, R.F.; VIEIRA, R.F.; VIANA, A.P.; FREITAS, S.P. Influência do estádio de maturação dos frutos e período de armazenamento das sementes no vigor das sementes de mamão dos grupos Solo e Formosa. In: Reunião de Pesquisa do Frutimamão, 2., 2004. Anais... Campos de Goytacazes: Universidade Estadual do Norte Fluminense Darcy Ribeiro, 2004. p.71-75.

ARUMUGAM, S.; SHANMUGAVELU, K.G. Estudies on the viability of papaya seeds under different environments. Seed Research, v.5, n.1, p.23-31, 1977.

BETTY, M.; FINCH-SAVAGE, W.E. Respiratory enzyme activities during germination in Brassica seed lots of differing vigour. Seed Science Research, v.6, p.165-173, 1996.

BRANDÃO JR., D.S.; CARVALHO, M.L.M.; VIEIRA, M.G.G.C. Variações eletroforéticas de proteínas e isoenzimas relativas à deterioração de sementes de milho envelhecidas artificialmente. Revista Brasileira de Sementes, v.21, n.1, p.114-121, 1999.

BRASIL. Ministério da Agricultura e Reforma Agrária. Secretaria Nacional de Defesa Agropecuaria. Departamento Nacional de produção Vegetal. Coordenação de Laboratório Vegetal. Regras para análise de sementes. Brasília, DF, 1992. 365p.

CARVALHO, N.M.; NAKAGAWA, J. Sementes: ciência, tecnologia e produção.. Jaboticabal: FUNEP, 2000. 588 p.

CHAUNNAN, K.P.S.; GOPINATHAN, M.C.; BABU, C.R. Eletrophoretic variations of proteins and enzymes in relation to seed quality. Seed Science and Technology, v.13, n.3, p. 629-641, 1985.

CONKLE, M. T.; HODGSKISS, P. D.; NUNNALLY, L. B.; HUNTER, S. C. Starch gel electrophoresis of conifer seeds: a laboratory manual. Berkerley, USDA, Forest
Service, 1982. 18p. (Gen. tech. rep., PSW-64).

COPELAND, L.O.; McDONALD Jr., M.B. Principles of seed science and technology. New York: McMillan, 1995. $321 \mathrm{p}$.

CROMARTY, A., ELLIS, R.H.; E.H. ROBERTS. 1982. The Design of Seed Storage Facilities for Genetic Conservation. International Board for Plant Genetic Resources, Rome, Revised 1985.

DUFF, S.M.G.; SARATH, G.; PLAXTON, W.C. The role of acid phosphatases in plant phosphorus metabolism. Physiolologia Plantarum, v.90, p.791-800, 1994.

ELLIS, R.H.; HONG, T.D.; ROBERTS, E.H. Effect of temperature and moisture on the germination of papaya seeds. Seed Science Research, v.1, n.1, p.69-72, 1991.

FREITAS, R.A.; DIAS, D.C.F.S; OLIVEIRA, M.G.A.; DIAS, L.A.S.; JOSÉ, I.C. Physiological and biochemical changes in naturally and artificially aged cottonseeds. Seed Science and Technology, v.34, n.2, p.253-264, 2006.

KALPANA, R.; MADHAVA RAO, K.V. Lipid changes during accelerated ageing of seeds of pigeonpea (Cajanus cajan (L.) Millsp.) cultivars. Seed Science and Technology, v.24, p.475-483, 1996.

MAGILL, W.; DEIGHTON, N.; PRITCHARD, H.W. Physiological and biochemical-studies of seed storage parameters in carica-papaya. Proceedings of the Royal Society of Edinburgh Section B-Biological Sciences, v.102, n.2, p.439-442, 1994.

MARTINS, G.N.; SILVA, R.F.; ARAÚJO, E.F.; PEREIRA, M.G.; VIEIRA, H.D.; VIANA, A.P. Influência do tipo de fruto, peso específico das sementes e período de armazenamento na qualidade fisiológica de sementes de mamão do grupo Formosa. Revista Brasileira de Sementes, v.27, n.2, p.12-17, 2005.

OLIVEIRA, J.R.P.; TRINDADE, A.V. Propagação e formação do pomar. In: TRINDADE, A.V. (org.). Mamão. Produção: aspectos técnicos. Brasília, DF: Embrapa Comunicação para Transferência de Tecnologia, 2000. p.20-25.

PADILHA, L.; REIS, M.S.; ARAÚJO, E.F.; SEDIYAMA, C.S.; ROCHA, V.S. Efeito de embalagens na viabilidade de sementes de soja armazenadas com diferentes graus de umidade inicial. Revista Brasileira de Sementes, v.20, n.2, p.277-281, 1998 .

RAJAGOPAL, A.S.M.; SEN-MANDI, S. Studies on acid and alkaline phosphatases in aged rice embryos. Seed Science and Technology, v.20, p.215-222, 1992. 
SALOMÃO, A.N.; MUNDIM, R.C. Germination of papaya seed in response to desiccation, exposure to subzero temperatures, and gibberellic acid. HortScience, v.35, n.5, p.904-906, 2000.

SANTOS, R.C.A.; SAMPAIO, L.S.V.; COSTA, J.A. Condição ambiental grau de umidade e embalagem na viabilidade e no vigor de sementes de mamão. Revista Brasileira de Sementes, v.21, n.2, p.194-202, 1999.

SAS Institute. Statistical user's guide. NC: SAS Institute Inc, 1989. 846p.

SHATTERS, R.G.JR.;ABDELGHANY,A.;ELBAGOURY, O.; WEST, S.H. Soybean seed deterioration and response to priming: changes in specific enzyme activities in extracts from dry and germinating seeds. Seed Science Research, v.4, n.1, p.33-41, 1994.

SHEN, T.Y.; ODEN, P.C. Activity of sucrose synthase, soluble acid invertase and fumarase in germinating seeds of Scots pine (Pinus sylvestris L.) of different quality. Seed Science and Technology, v.27, n.3, p.825-838, 1999.

SINGH, R.M.; SINGH, I.D. Effects methods and duration of storage on seed germination and seedling vigour in papaya. Seed Research, v.9, n.1, p.67-72, 1981.

SOLTIS, D.E.; HAUFLER, C.H.; DARROW, D.C. Starchgel electrophoresis of ferns - a compilation of grinding buffers, gel and electrode buffers, and staining schedules. American Fern Journal, v.73, n.1, p.9-27, 1983.

SPINOLA, M.C.M.; CÍCERO, S.M.; MELO, M. Alterações bioquímicas e fisiológicas em sementes de milho causadas pelo envelhecimento acelerado. Scientia Agricola, v.57, n.2, p.263-270, 2000.
SUNG, J.M.; JENG, T.L. Lipid peroxidation and peroxidescavenging enzymes associated with accelerated ageing of peanut seed. Physiologia Plantarum, v.91, n.1, p.51-55, 1994.

TAIZ, L.; ZEIGER, E. Fisiologia vegetal. 3.ed. Porto Alegre: Artmed, 1994,720p.

TOKUHISA, D.; DIAS, D.C.F.S.; ALVARENGA, E.M.; DIAS, L.A.S.; MARIN, S.L.D. Tratamentos para superação da dormência em sementes de mamão. Revista Brasileira de Sementes, v.29, n.1, p.131-139, 2007a.

TOKUHISA, D.; DIAS, D.C.F.S.; ALVARENGA, E.M.; HILST, P.C.; DEMUNER, A.J. Compostos fenólicos inibidores da germinação de sementes de mamão. Revista Brasileira de Sementes, v.29, n.3, p.161-168, 2007 b.

VIEIRA, M.G.G.C.Utilização de marcadores moleculares no monitoramento da qualidade sanitária e nível de deterioração de sementes de algodoeiro (Gossypium hirsutum L.). 1996. 114f. Tese (Doutorado em Fitotecnia) - Universidade Federal de Lavras, Lavras, 1996.

VIGGIANO, J.R.; SILVA, R.F.; VIEIRA, H.D. Ocorrência de dormência em sementes de mamão (Carica papaya L.). Sementes Online, v.1, n.1, p.6-10, 2000a.

VIGGIANO, J.R.; VIEIRA, H.D.; SILVA, R.F.; ARAUJO, E.F.; VIANA, A.P. Conservação de sementes de mamão (Carica papaya L.) em função do teor de água, tipo de embalagem e ambiente de armazenamento. Revista Brasileira de Sementes, v.22, n.2, p.279-287, 2000 b.

YAHIRO, M.; ORYOJI, Y. Effects of gibberellin and cytokinin treatments on the promotion of germination in papaya, Carica papaya L. seeds. Memorial Faculty Agriculture Kogoshima University, v.16, n.1, p.45-51, 1980. 